\title{
The Relationship between Earnings Management and Stock Price Liquidity
}

\author{
Shehadeh S. Arar ${ }^{1}$ Emad Al-Sheikh ${ }^{1} \&$ Abdullah S. $\operatorname{Hardan}^{1}$ \\ ${ }^{1}$ Applied Science Private University, Amman, Jordan \\ Correspondence: Emad Al-Sheikh, Applied Science Private University, Amman, Jordan. E-mail: \\ emad_sh@asu.edu.jo \\ Received: January 21, 2018 \\ Accepted: February 25, 2018 \\ Online Published: March 18, 2018 \\ doi:10.5539/ijbm.v13n4p99 \\ URL: https://doi.org/10.5539/ijbm.v13n4p99
}

\begin{abstract}
This study aimed to examine the relationship between Earning's Management and the Stock Price Liquidity for a selected sample of (49) Jordanian Service Companies listed on Amman stock market for The period of (2010-2015), the importance of this study comes from The Obvious effect of Earning's Management on the Companies Performances by manipulating the Financial reports in Positive or Negative way, therefore this study attempted to examine such impact or Relationship between the dependent variable (Stock Liquidity) and The independent variable (Earning's Management), Using the Jones Modified Model (1995) through the description.

Analysis to find out The Earning's Management Practice and using The (SPSS) analysis System to Prove The study assumption.

The outcomes of this study indicated a non-significant relationship between the Earning's Management and the Stock Price Liquidity in The Jordanian Service Companies. In addition there were the Recommendation of using a concept of linking the corporate Governance with some Earning's Management, through some Accounting application approved by the international financial Standards to attain the use of positive Earning's Management within Companies to improve the overall performance and serve all the Users of the financial reports.
\end{abstract}

Keywords: earning's management, service companies, stock price liquidity

\section{Theoretical Framework}

\subsection{Introductions}

Increasing interest of the business sectors on the issues of Earnings management because of the changes and developments of the business environment, in addition to what happened in recent years of some financial crises and the collapse of some international companies, and the fact that the process of Earnings management is closely linked to financial accounting work in general in any company On the different economic sectors, Earnings management may be considered a strong indicator of corporate activity. Which the Stock prices can be measured in the present value of the company's future profits because the low-profit companies have low share prices (Rahman, Moniruzzaman, \& Sharif, 2013).

There are several uses for Earnings management, some negative, like, the administration's attempt to reach predetermined numbers related to the performance of the company, through the manipulation of profits, where the management interests focused on rewards and incentives associated with these profits without considering their impact on the company performance. The other face of Earnings management use are the positive side, like, the use of the concept of direct or actual profit management, which depends on the timing of investment and control the estimated expenses in companies to reach the profit or return required, or use profit management to reduce income which related to reduce corporate taxes .

The interaction and correlation between accounting and corporate stocks can drive companies to use the Earnings management to reach the expectation of stock market analysts, since the Investors usually rely on the views and expectations of stock market analysts to see successful companies, because usually the companies that meet these expectations or exceed these expectations are often with higher profits or returns, which stimulates investors to invest in these companies shares, leading to higher shares and increase in the liquidity.

Based on the above, the subject of Earnings management is interested by studies and research to determine the 
extent of its spread in the business market and its role in achieving higher or lower levels of returns and profits using different methods of accounting, in addition to their relationship and an impact on the liquidity of shares of companies.

There are many models that have been used to explore the Earnings management; most of research studies models discovered the earnings management through Discretionary Accruals during the period from 1985 to 1995.

The aim of ( Dechow, Sloan, and Sweeney, 1995) study was to evaluate the models used to measure Discretionary Accruals to detect Earnings management. The study included the following models:

Healy Model (1985): This model uses mean total accruals to measure non discretionary accruals by dividing the total accruals for a given year over to the total assets for the previous year.

De Angelo Model (1986): This model uses total accruals for the previous year as the measure of non discretionary accruals.

Dechow and Sloan (1991) - Industry Model: This model assumes that the change in non discretionary accruals is common for all companies affiliated to the same activity sector. This model estimates the non discretionary accruals by divided the median of total accruals to the total assets of all firms in the industry for the previous year.

Jones Model (1991) introduces new variables such as changes in revenues, property, plant and equipment, so as to control the impact of change in a firm's economic conditions on nondiscretionary accruals.

Modified Jones Model (1995) assumes that the change in sales on account result from Earnings management. Therefore, Dechow and Sloan modified the Jones model (1991) by introducing the change in accounts receivable.

The results of (Dechow et al., 1995) concluded that modified Jones is the most effective model in detecting Earnings management practices.

According to these results; this study used Jones' Modified Model 1995 for the purpose of identify the relationship between the Earnings management and the liquidity of shares for the Jordanian service sector. This study has been applied to the service sector because the importance of this sector as well as it is divided into several economic sectors within the service sector and many of these sectors contain the most successful with most important and influential companies in the national economy, division these sectors according to the Amman Stock Exchange for the year 2016 are (health, commercial, educational, communications, energy, transport, hotels and tourism, media).

\subsection{The Study Problem}

The Investments increase in the financial markets requires an attempt to understand the nature of the company's performance with the main reasons that may directly or indirectly affect on the company's performance.

Since most previous studies have found a relationship between the Earnings management and the company's performance throw the financial performance, and the correlation of this relationship effect on the financial reports directly, while these reports are the main tool for investors to make the investment decision of (buy, sell or not invest) in the shares of companies (Rashid, Noor, Matsuki, Abrahman, \& Omar, 2016).

For that the problem of Earnings management and its relation to the liquidity of stocks in companies should be investigated by answering the following question:

Is there a relationship between the Earnings management and the liquidity of shares of public service companies?

\subsection{The study Objectives}

The study aims at uncovering the relationship between the practice of service companies listed on the Amman Stock Exchange to Earnings management and liquidity of shares in these companies.

The service sector has been chosen for its importance in the Jordanian economy and the fact that the financial statements of this sector attract the interest of several parties (such as investors, banks with a view to financing, owners). The study also predicts that there is a possibility to practice the Earnings management in this sector and the influence of this practice on the Liquidity of the company's shares.

\subsection{The Importance of Studying}

The importance of Earnings management comes from the impact on corporate performance in general and its 
association with the global financial and economic crises in recent years. Moreover, companies try to use the concept of the Earnings management to face the financial crises by showing a positive financial performance, because the impact on the liquidity of corporate shares.

Therefore, the importance of this study comes from the following reasons:

First: the importance of the subject of earnings management in general, and is considered a modern accounting topics despite the existence of studies a good number of previous studies.

Second: Liquidity of shares is important in investing and linking this liquidity to Earnings management may have an important role in making investment decisions.

\subsection{Hypothesis Development}

The study seeks to know the relationship between the Earnings management and the liquidity of shares in the Jordanian service companies listed on the Amman Stock Exchange. Hence, the following hypothesis was:

H0: There is a non significant relationship between Earnings management and stock liquidity in service companies listed on the Amman Stock Exchange during the study period

\section{Methodology and Limitation}

\subsection{Measurement}

The study contains a set of variables and below the definitions of these variables:

\section{Independent Variable (Earnings Management):}

Earnings management is measured by the following three equations (Khan, Amir, \& Sajjad, 2013):

$$
\begin{aligned}
& \text { Equation 1: } \mathrm{TA}=\mathrm{NDA}+\mathrm{DA} \\
& \text { Equation 2: } \mathrm{TA}=\mathrm{NI}-\mathrm{CFO}
\end{aligned}
$$

Equation 3: NDA

$$
\left.\mathrm{NDA}_{i, \mathrm{t}} / \mathrm{A} \mathbf{i}, \mathbf{t}-\mathbf{1}=\alpha 1(1 / \mathrm{A} \mathbf{i}, \mathbf{t}-\mathbf{1})+\alpha 2\left[\left(\Delta \mathrm{REV}_{\mathrm{i}, \mathrm{t}}-\Delta \mathrm{REC}_{\mathrm{i}, \mathrm{t}}\right) / \mathrm{A} \mathbf{i}, \mathbf{t}-\mathbf{1}\right)\right]+\alpha 3\left(\mathrm{PPE}_{\mathrm{i}, \mathrm{t}} / \mathrm{A} \mathbf{i}, \mathbf{t}-\mathbf{1}\right)
$$

Where:

$$
\begin{aligned}
& \text { TA }=\text { Total Accruals } \\
& \text { NDA = Non Discretionary Accruals } \\
& \text { DA = Discretionary Accruals } \\
& \mathrm{NI}=\text { Net Income } \\
& \mathrm{CFO}=\text { Cash Flow from Operation } \\
& \text { At-1 = Assets of Previous Year, } \\
& \text { Dependent Variable (Stock Liquidity): }
\end{aligned}
$$

The dependent variable will be calculated by:

Dependent Variable $=$ High Stock Price - Low Stock Price.

\subsection{Sample and Data}

The study samples are the service companies listed on the Amman Stock Exchange (49) companies, which are traded according to the latest information from the Amman Stock Exchange (2016).

The study will cover the financial reports of public shareholding companies listed on the Amman Stock Exchange during the period 2010-2015. The year 2016 was not included in the study period because the final accounts for 2016 were not yet published when preparing the study.

\subsection{Study Determinants}

The study on the service sector led to face some determinants, such as the divisions of companies according to the Amman Stock Exchange within the service sector, because some sectors have two companies and in the other sector there are ten companies, in addition the financial performance of the companies vary from one sector to another, regardless to previous determinants the study applied on all sectors and companies by distinguishing each type of service companies and determining the effect of earnings management practice on the liquidity of shares, first on the service companies in general, and secondly on each sector separately. 


\section{Results}

For the purpose of analyzing the information and results in more detail, service companies were divided according to the type of services provided by the number of companies in each service sector, all according to the divisions of the Amman Stock Exchange and a total of (49) companies.

Table 1. Number of companies in each sector of service sector companies

NO Sector Number of companies in each sector of service companies

\begin{tabular}{ll}
\hline 1 Health & 4 \\
\hline 2 Educational & 6 \\
3 Hotels and Tourism & 10 \\
4 Transport & 10 \\
5 Communications & 2 \\
6 Media & 2 \\
7 Energy & 3 \\
8 Commercial & 12 \\
Total & 49 \\
\hline
\end{tabular}

After presenting the sectors of the companies and their numbers, study will analyze results in the descriptive analysis of the variables of the study and put them in graphs to identify the extent of Earnings management practice in the service companies listed on the Amman Stock Exchange and to summarize the data for the equation of discovery of earnings management practice, In the service sector companies during the years of study (2010-2015) were (113) views as in the previous table and the total data that was analyzed for all service sector companies was (49 companies * 6 years $=294$ value) as in table $(4-5)$, and a simple division of the total earnings Management Practice (113) views on the total data collected data for companies (294 value) $(113 / 294=$ $0.38 \%)$. The result is $38 \%$, this figure means the average of practicing the Earning management for all companies of service sector in Amman stock exchange market for six years are 38\% in other words (38\% of the six years (study years) there is an Earnings management practice in the companies).

The previous percentages are considered a general percentage of the service sector. Therefore, we will analyze more in detail the components of the sector as in the following steps divided into five main categories:

- Category 1 percentages of Earnings management practice in each sector of the service sector:

The percentage of earnings management practice was calculated by dividing the number of views per sector to the total number of views (113 views) in all service companies sectors. Below the chart for this category.

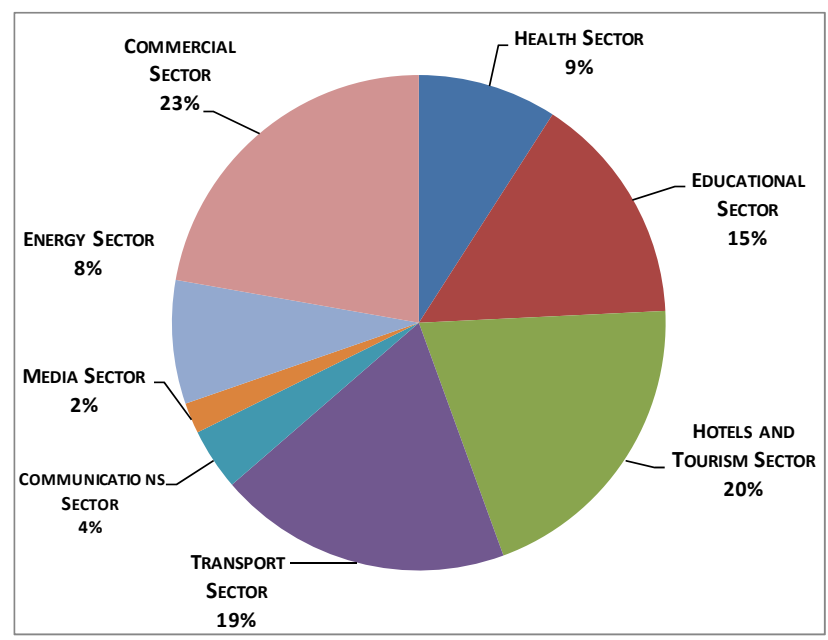

Figure 1. Percentages of Earnings management practice in each service sector

Category 2 Percentage of Earnings management practices in each sector separately, to the total service sectors: 
This category calculated the percentages throw two steps as below:-

- $\quad$ Each sector will be calculated separately through the number of companies in each sector. For example, the health sector has 4 companies; the number of views of Earnings management practice in this sector is 10 views. And it was noticed that the highest frequency of the Earnings management practice for all companies of service sector during the study years was (4), so the study will assume that the highest possible frequency views of Earnings management practice for the healthy sector is $(4 * 4)$ which equal 16 , and by divided the actual health sector Views on the highest possible views of this sector produces the following percentage $(10 / 16=0.63)$.

- In the same way will calculate all other sectors percentages, after that these values are then collected to obtain a sum equal to (4.6) which is the total of all percentages, back to pervious example the health sector percentage of earnings management practice depending on this category is $14 \%(0.63 / 4.6)$ of the total Earnings management practice for the service sector.

The advantages of this category results compare to the first category results are the accurate of the results analysis because it is taking into account the size of each sector within the service sector, so the results will be more reliable.

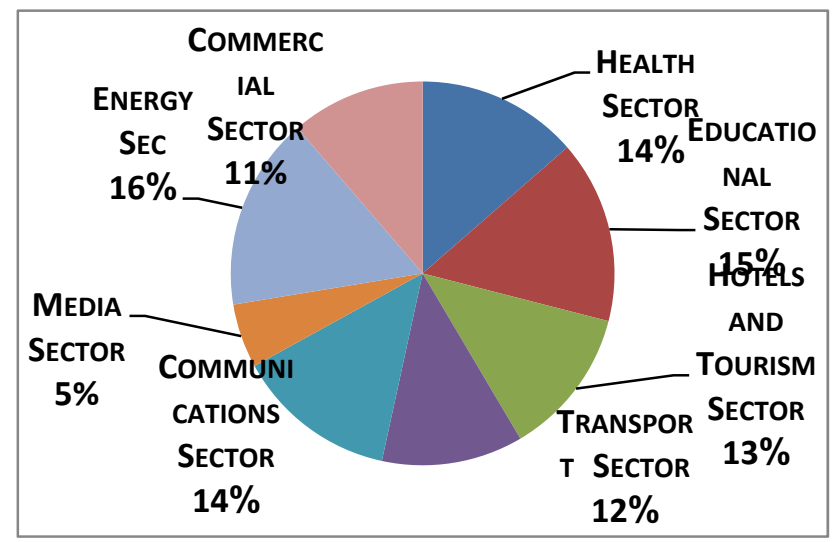

Figur 2. Percentage of Earnings management practices in each sector separately

- Category 3 Earnings Management practice by years of the study:

Earnings management was measured by years of study, and the chart for this category is as below:

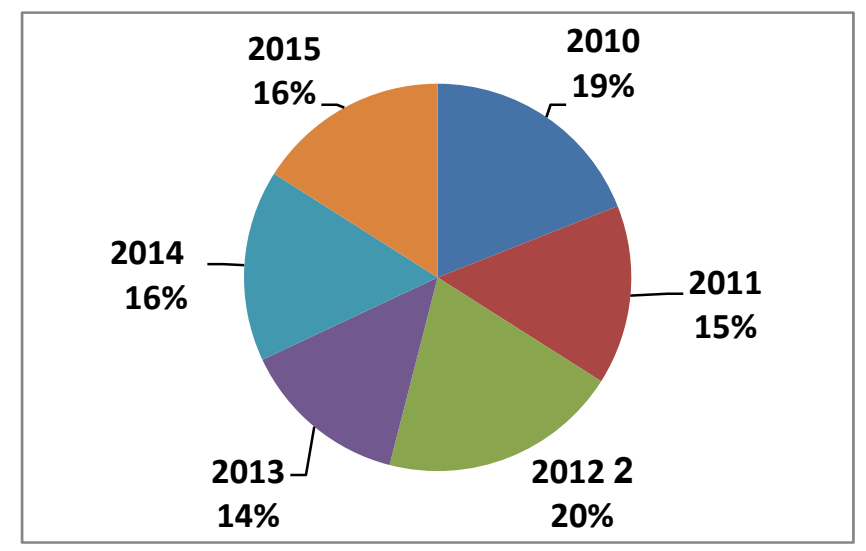

Figur 3. Earnings Management practice by years

- Category 4 the positive Earnings management practice by years of the study:

This category is based on measuring the management of positive Earnings management which related with increasing profits in the service companies during the years of the study. 


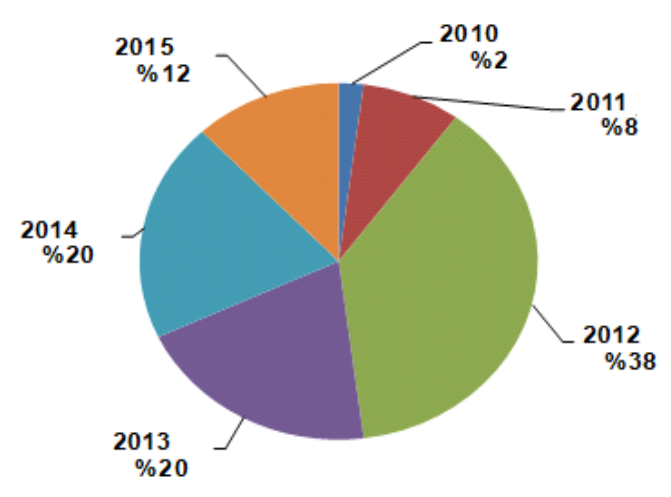

Figure 4. Percentage of the positive Earnings management practice by years

Category 5 liquidity Ratios by years of the study

This category is based on studying the liquidity ratios in all sectors within the service sector through the calculation of the highest stock values during the study period minus the lowest stock values divided by the highest value for each company separately, and then calculating the liquidity ratios in each sector as shown in the following Chart:

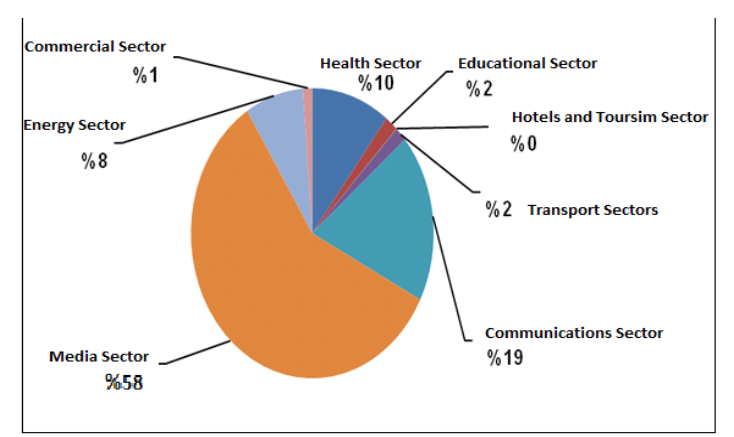

Figure 5. Liquidity ratios by years

\section{Test Study Hypothesis}

H0: There is a non significant relationship between Earnings management and stock liquidity in service companies listed on the Amman Stock Exchange during the study period.

The results of the hypothesis test are shown in the statistical program (SPSS) in the following table:

Table 2. Study hypothesis test results (dependent variable: stock liquidity) Pearson test

\begin{tabular}{lllll}
\hline Variable Name & & Correlation & Sig & Views \\
\hline Earnings Management & & -0.098 & 0.151 & 113 \\
Adjusted R2 & $\mathrm{F}$ & $\mathrm{T}$ & $\mathrm{Sig}$ & $\mathrm{B}$ \\
0.010 & 1.072 & -1.035 & 0.151 & -0.098 \\
\hline
\end{tabular}

The previous table shows the results of the main hypothesis test in the study. It is noticed through the review of the results that there is a negative correlation relationship between the variables because the correlation is $(-0.098)$ between the Earnings management and liquidity of stocks, which means that the relationship is reversed in the effect between them.

The level of the P-Value (sig) is higher than the level of significant accepted statistical value equal to (0.05) where P-Value (Sig) is (0.151), and also appeared a negative and non significant relationship with the other 
results of the study analysis because the $\mathrm{T}$ value is $(\mathrm{T}=-1.335)$, as shown result measured by Adjusted $\mathrm{R} 2$, which is equal to (Adjusted $\mathrm{R} 2=0.010$ ). Which indicates that the dependent variable Explain about 0.010 of the independent variable and $\mathrm{F}(=1.072)$.

\section{Conclusions}

The study concluded the following conclusions:

The rate of Earnings management practice during the study years for all service sector companies was (38\%) during the study period (2010-2015).

The energy sector and the education sector were the most profitable sectors. This is explained by the fact that these sectors are among the most successful sectors within the service sector in recent years, especially with the increase in the value of oil materials for the energy sector and the growth and expansion of educational sectors within the service sector.

The media sector and the commercial sector were among the least profitable companies, and this can be explained in the media sector due to the low number of companies in this sector, namely Al-Rai newspaper and Al-Dustour newspaper, as well as the concentration of government ownership in these companies, And its explanation for the commercial sector because of the low profitability of companies in this sector in the years of study compared to other companies in other sectors.

The most successful sectors were the most practicing to the Earnings management compared to the less successful companies, which was the least practicing to the Earnings management. This leads to a result of a positive relationship between Earnings management and success of the companies, as well as the size of companies had a role in the practice of Earnings management where larger companies have had greater Earnings management practicing as in the energy sector.

The study found that the years $(2013,2011)$ are the highest discovered years of practicing the Earnings management during the years of study and sorted in descending. While the years $(2013,2011)$ are the least discovered years of practicing the Earnings management during the years of study and sorted in ascending.

Note from the previous point that in a year is the discovery of the practicing the Earnings management immediately followed by a year in which the discovery of practicing of the Earnings management for less than a year previous and so throughout the years of study, which means that the service sector companies exercise Earnings management to meet the economic conditions facing companies during their work, For reasons of developing and increasing the efficiency of companies.

Positive Earnings management was $44 \%$, which means that slightly less than half is a practice to manage positive earnings in order to increase the profits of companies during the study years. And by linking the discovery of the practicing the Earnings management in general with the discovery of practicing the positive earnings management during the years of study noted that the year (2012) was the most discovery year for the practicing the Earnings management and most of the discovery of the practicing the positive Earnings management This can be explained through the in two opinion sides, First the year(2012) one of the best years of financial performance for service sector companies in the study years, Therefore, Earnings management, especially positive ones, has been used to increase bonuses and incentives for managers. The second opinion side is that the year (2012) was one of the worst years of study for financial performance for service sector companies the study years, because the most companies in the Jordanian market usually are the companies based on individual or family ownership and most of these companies may not try to increase the profits, based on previous vision the second opinion will be rejected, so depending on first side opinion which says that the year (2012) with practicing earnings management in general with practicing the positive Earnings management in the same time is the best year for the financial performance of companies during the years of study.

Analysis of the stock liquidity ratios of service sector companies found that the most liquid sector is the media sector, which, as mentioned earlier, is one of the least profitable sectors according to the study. This is due to the reason mentioned earlier that the media sector is among the least sectors in numbers of companies in addition to the rise in government ownership, and the energy sector, which was one of the most profitable sectors, was ranked fourth in terms of eight positions for stock liquidity. This could lead to a conclusion that there is no positive relationship between the Earnings Management and stock Liquidity.

Accepted the hypothesis of the study (There is non-significant relationship between earnings management and stock liquidity in service companies listed on the Amman Stock Exchange during the study period), which leads to an initial result that the earnings management can be used to develop and expansion the company's performance. 


\section{Recommendations}

The study recommends trying to expand the study of the relationship between the practicing the Earnings management and the performance of companies to other sectors and to try to identify the extent of earnings management practice in successful companies and by answering the following question (Is the more successful companies used the profit management more?).

The study recommends increasing the search for the practice of the Earnings management in the years of business of companies to try to explain more of the reasons for the high practice of Earnings management during certain years and decrease in other years.

Emphasize on the practicing the Earnings management in a positive manner that helps to develop companies based on plans prepared in advance and clearly and practice is not only related to emergency circumstances.

The study recommends expanding the research on the rate of profit management practice in Jordanian companies in general and in the service sector companies in particular and for many other years, so that researchers can know the meaning of these percentages and are these percentages on average, And the meaning of each case.

As in the previous point, we should also expand our research on the positive and negative Earnings management over many other years, so that researchers can explain and correlate the rise or fall of these ratios with the performance of companies.

Trying to apply this study to all companies in the Amman stock exchange market to ensure that the results reached in the service sector are in line with the results that can be reached in all sectors on the Amman Stock Exchange, thus increasing the ability to explain all the rates of Earnings management practice in the Jordanian market In general and linked to economic conditions and corporate performance.

The study recommends examining the relationship between Earnings management with other aspects of performance in companies such as (size of assets, equity ratios) to identify the impact of this concept on all aspects can influence in performance in the service sector companies.

Since the Jordanian law requires companies to follow the principles of corporate governance, the study recommends linking the principle of corporate governance to the practice of Earnings management for two main reasons: First, because part of the Earnings management practice is done through certain accounting policies accepted by the (IFRS) International Financial Reporting Standards, Second reach the optimal use of Earnings management practices that help increase the efficiency of companies and lead to their expansion without affecting the parties associated with the financial statements of those companies.

\section{References}

Al-Mousawi, R. J., \& Al-Thuneibat, A. (2011) . The Effect of Audit Quality on the Earnings Management Activities. Dirasat Administrative Sciences, 38(2), 614-628.

Amman Stock Exchange. (2016). Retrieved from https://www.ase.com.jo

Bodie, Zvi., Kane, Alex.,\& Marcus Alan, J. (2013). Essentials of Investments. UK: McGraw-Hill.

Chang, Chun-Chia. (2006). The Impact of Earnings Management on the Predictive Ability of Accruals: Implications for Earnings Quality (Unpublished PHD thesis). University of Houston, USA.

Chapman, C. J., \& Steenburgh, T. J. (2010). An Investment of Earnings Management through Marketing Actions. Working Paper. Harvard Business School, 57(1), 72-92.

Dechow, P. M., \& Skinner, D. J. (2000). Earnings Management: Reconciling the Views of Accounting Academics. Practitioners and Regulators. American Accounting Association, 14(2), 235-250.

Dechow, P. M., Sloan, R. G., \& Sweeney, A. P. (1995). Detecting Earnings Management. The Accounting Review, 70(2), 193-225.

Gitman, L. J., \& Zutter, C. J. (2012). Principles of Managerial Finance. UK: Pearson.

Hosseini, M., Chalestori, K., Nadafi, H., Saed, R., \& Ebrahimi, E. (2016). A Study on the Relationship between Earnings Management Incentives and Earnings Response Coefficient. Procedia Economics and Finance, 36, 232-243. https://doi.org/10.1016/S2212-5671(16)30034-X

Khan, A., \& Sajjad. (2013). Earnings Management and Stock Prices Liquidity. Journal of Business and Economic Management, 1(3), 36-40.

Kumar, J. (2003). Does Ownership Structure Influence Firm Value? Evidence from India. the Journal of Entrepreneurial Finance and Business Ventures, 9(2), 61-93. https://doi.org/10.2139/ssrn.464521 
Ma, R., Anderson, H. D., \& Marshall, B. R. (2015). International stock market liquidity: a review. Managerial Finance, 42(2), 118-135. https://doi.org/10.1108/MF-04-2015-0096

Rahman, M., Moniruzzaman, M., \& Sharif, J. (2013). Techniques, Motives and Controls of Earnings Management. International Journal of Information Technology and Business Management, 11(1), 22-34.

Rashid, N., Noor, R., Matsuki, N., Abrahman, N., \& Omar, N. (2016).The Longitudinal Study of Earnings Management: Analysis on Companies Financial Abilities. Procedia Economics and Finance, 35, 136-145. https://doi.org/10.1016/S2212-5671(16)00018-6

Roychowdhury, Sugata. (2006). Earnings Management through Real Activities Manipulation. Journal of Accounting and Economics, 42, 335-370. https://doi.org/10.1016/j.jacceco.2006.01.002

\section{Copyrights}

Copyright for this article is retained by the author(s), with first publication rights granted to the journal.

This is an open-access article distributed under the terms and conditions of the Creative Commons Attribution license (http://creativecommons.org/licenses/by/4.0/). 